\title{
Iranian EFL Students Assertiveness and Their Writing Ability
}

\author{
Zahra Mohammadi Salari" , Helen Behtaj, Masoud Sharififar \\ Department of foreign languages,Kerman Institute of Higher Education , Kerman, Iran \\ *Corresponding Author: z.mohammadisalari@gmail.com
}

Copyright $@ 2015$ Horizon Research Publishing All rights reserved.

\begin{abstract}
As human is a social creature, he/she needs social abilities to communicate and interact to society. A person with higher social abilities can achieve more success and happiness in social interactions. Assertiveness is one style of personality behavior which is the individual's ability to state his/her desires without violating the others' right. In educational setting, learners can take the advantages of assertiveness to achieve success in their course of study. The present study investigated the relationship between Iranian EFL learners' assertiveness and their writing ability. The participants $(n=50)$ filled an 80 -item self-perception questionnaire developed by [9]. A test of writing (writing section of PET) was provided for learners to measure their writing ability. Based on learners' performance on questionnaire, they were divided into two main groups of assertive and non-assertive learners. The results of correlation showed that there is a statistical significant relationship between assertiveness and writing ability. The results of ANOVA indicated that personality behavior groups were significantly different from each other regarding their performance on writing test. It was also reported that assertive learners outperformed on writing test. The results of this study may help EFL learners to develop their positive personality skills and achieve success in language learning.
\end{abstract}

Keywords Personality Behavior, Assertiveness, Writing Ability

\section{Introduction}

Social skills play a significant role in individuals' lives. A person with higher social abilities can achieve more success and happiness in his/her social interactions. This issue is highlighted when it is considered in teaching and learning environment. The inability of some English Foreign Language learners in interpersonal communication and oral argumentation may be partly due to the lack of assertiveness. Apparently communication and expressing ideas are among the most important components of language learning. As [4, p.197] stated, "Assertiveness is open and clear expression, firm and fluent conversation, and quick spontaneous answers". Assertiveness can play a significant role in language learning settings. Assertiveness is one of the three common styles of behavior a person can have. Other styles of behavior are aggressiveness and passiveness. Aggressiveness is a behavior style that individuals ask everyone to know their ideas, but often does not let others express their opinions in the same manner. Assertiveness may be confused with aggression because both of them involve standing up for one's right and expressing one's needs. The difference between them is that individuals behaving assertively will express their thoughts and feeling while respecting others. According to [8], "they assume the best about people, respect themselves, and think "win-win" and try to compromise" (P. 3). In contrast, those who behave aggressively may "employ tactics that are disrespectful, manipulative, demeaning, or abusive" [8, P. 3]. They have negative attitude toward the motives of others and they do not consider the other person's point of view at all. "They win at the expense of others, and create unnecessary conflict" [8, P. 3].

Passiveness refers to the kind of personality behavior that individuals express in order to avoid conflict as much as possible. In such kind of personality behavior, people hide their personal needs. A person with passive behavior may be easily hurt. Thus, Assertiveness is an optimal style of behavior while other two carry negative connotations.

$[6, p .1]$ stated that "writing involves composing"; it is the ability to tell pieces of information narratively or descriptively and also to transform information argumentatively. Despite the fact that writing has been de-emphasized by the Communicative Approaches, which their emphases have been on oral proficiency; the "ideas from writing-to-learn, writing across the curriculum, and writing for academic purposes movements in composition and English as a Second Language have all had an impact on thinking about the place of writing in second language education" [5, p. 6]. In fact approaches to writing without considering the two factors of some particular social and cognitive factors is nonsense. 


\section{Theoretical Framework}

This study uses an eclectic theoretical framework, assertiveness proposed by Townend's model (1991), and regarding writing skill the researcher uses White et al, [11]. The reason for using this model is that he has offered perhaps the most detailed definition of the construct of assertiveness. He noticed assertiveness is being made of 10 levels, including:1) assertiveness is about self respect and respect for others; 2)assertiveness is about positive recognition; 3)assertiveness is about positive emotion, thinking, and imagining;4)assertiveness is about authentic connection with self and others; 5)assertiveness is about meaning and purpose; 6) assertiveness is about listening to and trusting intuition;7) assertiveness is about making mind, body, and brain connections;8) assertiveness is about feeling secure;9) assertiveness is about physical, intellectual, emotional, and spiritual awareness and integration;10)assertiveness is about acceptance and mindfulness. Regarding assertiveness, definition of assertiveness and differences between assertive and non-assertive behavior have been proposed by Townend. According to him assertiveness is the ability of a person to express and advocate his/her ideas, interests, feelings and thoughts appropriately and without anxiety while at the same time respecting these same characteristics in others. Townend introduced the key concept of assertiveness and the theory from which it is drawn, that is, assertiveness is about self-respect and respect for others. It is based on the theory of transactional analysis (TA).The theory of transactional analysis and in particular the concept of "life position" is a useful one in differentiating between assertiveness and nonassertiveness. The underlying philosophy of (TA) is that people are all born "ok" and that in childhood people make decisions based about themselves and others based on the kind of recognition and acknowledgment that they receive from significant others [10, p.11].The theory of "life position" proposes that the only healthy position is that of I'm ok: you're ok in which people feel secure and self-confident in themselves and respect others for who they are. The three other life positions are all non-assertive and are underpinned by feelings of insecurity and lack of self-confidence. [9] highlighted the difference between assertive (I'm ok; you're ok) and non-assertive behaviors of aggression (I'm ok ; you're not ok) and passivity(I'm not ok; you're ok) and at last submission (I'm not ok; you're not ok).

Regarding writing skill, White et al, [11], believed that the term "writing process" has been used to refer, in general, to the recursive, nonlinear approach, comprising of various stages such as generating ideas, structuring, drafting, revising, and editing, that student writers employ in order to create a piece of writing. The Process approaches to writing are the ones which their focuses have been mainly on some diverse classroom activities to promote language use, i.e. brainstorming, discussing, and re-writing. Writing involves "conscious effort and practice in composing, developing, and analyzing ideas" [6, p.1].
In order to take advantages of social life and interact in an effective and confident environment, it is important to learn a complex set of social skills such as assertiveness. Assertive children as well as assertive adults are particularly happier, healthier, more honest and less manipulative. They feel good about themselves, and find it easy to achieve what they plan to do in future. Regarding this issue, family, school and other social systems should consider individuals' natural rights and encourage them to express themselves. The importance of individual differences in language learning settings calls language practitioners' attentions to the researches and studies conducted on personality factors and individual differences. Language teachers need to be aware of these studies if they are to apply the theories of second or foreign language learning to their own classrooms. Although teachers are dealing with a class as a whole, it is sometimes necessary to consider the class consisting of individuals with different needs to be met. They need to apply strategies that meet each student's needs while considering the whole context. As a result, knowledge of various personality traits, cognitive styles, different kinds of learning strategy employed by learners, affective factors and their influences on language learning are crucial to every language teacher or practitioner.

This study was done to pursue two major objectives:

- To investigate the relation of assertiveness as a personality behavior to writing performance of Iranian English Foreign Language learners.

- To find whether there are any differences among English Foreign Language learners' personality behaviors (assertive behavior and non-assertive behavior) in their writing.

The following research questions were formulated in order to address the purposes of the study:

- To what extent is there any significant relationship between assertiveness and writing ability among English Foreign Language learners'?

- To what extent is there any significant difference among English Foreign Language learners' personality behaviors (assertive behavior and non-assertive behavior) and their writing ability?

The null hypotheses of this study are as follows:

- There is nosignificant relationship between assertiveness and writing ability among English Foreign Language learners.

- There is no significant difference among English Foreign Language learners' personality behaviors (assertive behavior and non-assertive behavior) and their writing ability.

\section{Method}

\section{Participants}

A sample of 50 males and females Iranian English Foreign Language students participated in this study. They were at 
intermediate level of English language proficiency. They were all native speakers of Persian. Their level of education varied from junior to senior. They studied English at ShahidBahonar University of Kerman. Their age range was between 20 to 25 years old.

\section{Instrumentation}

The materials used for the present study were self-perception questionnaire and writing section of Preliminary English Test (PET). Following is the detailed explanation of materials.

\section{Questionnaire}

Personality-traits questionnaire [9] was the major instrument to conduct this study. The purpose of the questionnaire is to identify the person's thoughts, ideas and emotions of him/herself and those of others. It is consisted of 80 items with 'yes' and 'no' options for respondents stating their agreement or disagreement. The questionnaire included four sub-scales of assertive, aggressive, submissive, and passive, each of which consisting of 20 items that were shuffled in the questionnaire items (appendix A).

The items of the questionnaire are related to features and characteristics which determine each of these four kinds of behaviors and personality traits and try to evaluate the testees with regard to assertive, aggressive, submissive, and passive features.

\section{English Writing Task}

In order to collect the data of the dependent variable, English Foreign Language learners' writing ability, the participants of study were required to answer the writing section of PET. Needless to say, PET is a standardized English language test (see appendix B) and its reliability and validity is guaranteed.

The writing section was composed of three parts. Part one consists of five questions about a holiday on a canal boat. Each question has two sentences that the participants should complete the second sentence so that it means the same as the first. It carried five marks. The second part consisted of one question that asks students to write an e-mail to a friend about moving to a new flat. The range of words to be used in writing is 35 to 45 words. It also carried five marks. Part 3 had two questions that learners are obliged to answer one of them. The students were asked to write a 100 -word story about the most important day of my life. It was assigned 15 marks. Totally, the writing section of PET had 25 marks. The writing essays were corrected by two raters.

\section{Procedure}

In order to explore the relationship between the construct of assertiveness and Iranian English Foreign Language learners' writing ability, a structured procedure was designed to collect data. All stages of study were conducted during normal class schedule in March 2013.

The study was initiated by administration of personality trait questionnaire. The necessary information and instruction regarding the questionnaire items was provided for the participants and they were asked to read and answer the questionnaire. The participants' highest scores on 4 sub-scales would reflect their dominant personality behavior. It is worth mentioning that, according to [9], being under the influence of one trait does not mean lack of other one. A person, who found to be assertive, might be passive or even aggressive in other cases.

The second step was administering the writing test. In the following class session, the writing ability of participants was measured by writing section of PET. As it was mentioned, the test had three parts and 7 questions. Five questions were open ended and two questions were composition writing. The writing papers were scored by two raters. The mean of two sets of scores were calculated and considered to conduct the statistical procedures.

\section{Results}

The personality questionnaire was administered among the 50 participants; the descriptive statistics of this administration appears below in Table1.

Table 1. Descriptive statistics of the obtained scores on personality questionnaire

\begin{tabular}{|c|c|c|c|c|c|}
\hline & $\mathrm{N}$ & Minimum & Maximum & Mean & $\begin{array}{c}\text { Std. } \\
\text { Deviation }\end{array}$ \\
\hline Assertiveness & 50 & 3.00 & 18.00 & 12.5400 & 3.75912 \\
\hline Aggressiveness & 50 & 2.00 & 16.00 & 7.7200 & 3.87056 \\
\hline Submissiveness & 50 & 1.00 & 13.00 & 6.1800 & 3.25570 \\
\hline Passiveness & 50 & .00 & 18.00 & 6.5600 & 4.32911 \\
\hline
\end{tabular}

The above scores are represented separately according to different personality styles in the following histograms for clearer understanding. Figure 1 shows the frequency of obtained scores on assertive factor.

Table 2.describes the frequency and percentage of participants according to their dominant personality behavior.

\begin{tabular}{|c|c|c|c|c|}
\hline $\begin{array}{c}\text { Personality } \\
\text { Traits }\end{array}$ & Frequency & Percent & $\begin{array}{c}\text { Valid } \\
\text { Percent }\end{array}$ & $\begin{array}{c}\text { Cumulative } \\
\text { Percent }\end{array}$ \\
\hline Assertive & 35 & 70.0 & 70.0 & 70.0 \\
\hline Aggressive & 8 & 16.0 & 16.0 & 86.0 \\
\hline Submissive & 3 & .0 & 6.0 & 92.0 \\
\hline Passive & 4 & 8.0 & 8.0 & 100.0 \\
\hline Total & 50 & 100.0 & 100.0 & \\
\hline
\end{tabular}

The schematic view of dominant personality behaviors in this study is shown in Figure 1. 


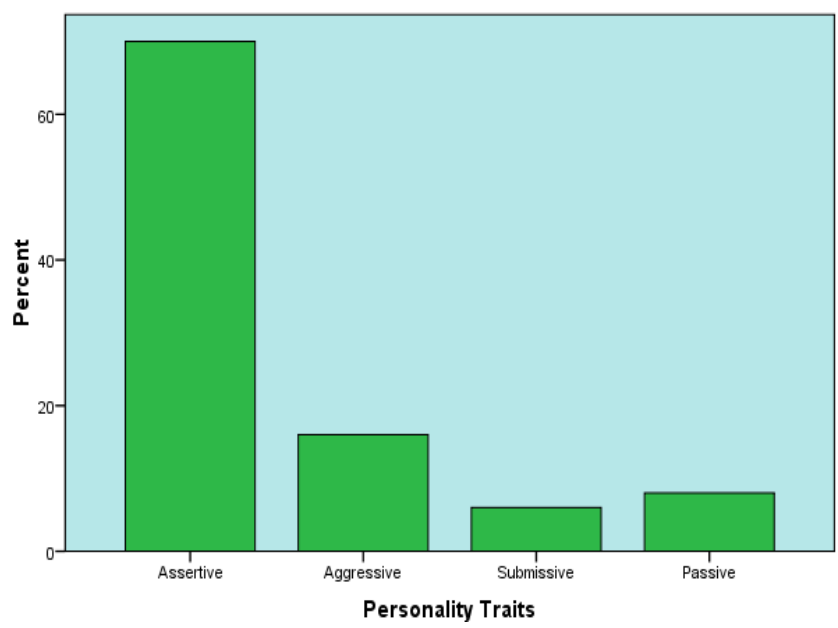

Figure 1.The percentage of dominant personality behavior of the participants

The descriptive statistics including mean, standard deviation, maximum and minimum of the scores of the participants on writing test corrected and rated by two scorers, is shown in Table 3 below.

Table 3. Descriptive statistics of the obtained scores on writing test

\begin{tabular}{|c|c|c|c|c|c|}
\hline & $\mathrm{N}$ & Minimum & Maximum & Mean & $\begin{array}{c}\text { Std. } \\
\text { Deviation }\end{array}$ \\
\hline $\begin{array}{c}\text { Writing } \\
\text { Score 1 }\end{array}$ & 50 & .00 & 24.00 & 15.42 & 4.99 \\
\hline $\begin{array}{c}\text { Writing } \\
\text { Score 2 }\end{array}$ & 50 & .00 & 23.00 & 15.78 & 4.64 \\
\hline $\begin{array}{c}\text { Valid N } \\
\text { (listwise) }\end{array}$ & 50 & & & & \\
\hline
\end{tabular}

A correlation coefficient was performed in order to calculate the inter-rater reliability of writing scores of two raters. The results, as shown in Table 4, indicated that the writing scores have a high and significant inter-rater reliability.

Table 4. Inter-rater reliability of the writing test

\begin{tabular}{|c|c|c|c|}
\hline & & $\begin{array}{c}\text { Writing } \\
\text { Score 1 }\end{array}$ & Writing Score 2 \\
\hline \multirow{4}{*}{$\begin{array}{l}\text { Writing } \\
\text { Score 1 }\end{array}$} & Pearson Correlation & 1 & $.954^{* *}$ \\
\cline { 2 - 4 } & Sig. (2-tailed) & & .000 \\
\cline { 2 - 4 } & $\mathrm{N}$ & 50 & 50 \\
\hline \multirow{3}{*}{$\begin{array}{l}\text { Writing } \\
\text { Score 2 }\end{array}$} & Pearson Correlation & $.954^{* *}$ & 1 \\
\cline { 2 - 4 } & Sig. (2-tailed) & .000 & \\
\cline { 2 - 4 } & $\mathrm{N}$ & 50 & 50 \\
\hline
\end{tabular}

\footnotetext{
**. Correlation is significant at the 0.01 level (2-tailed).
}

The average of two series of writing scores was calculated and was considered in this study. In order to answer the first research question of this study, a correlation coefficient was performed between the writing scores of participants and their assertiveness.
Table 5. Correlation between the writing and assertiveness

\begin{tabular}{|c|c|c|c|}
\hline & & Assertiveness & Writing \\
\hline \multirow{3}{*}{ Assertiveness } & $\begin{array}{c}\text { Pearson } \\
\text { Correlation }\end{array}$ & 1 & $.58 * *$ \\
\hline & Sig. (2-tailed) & & .001 \\
\hline & $\mathrm{N}$ & 50 & 50 \\
\hline \multirow{3}{*}{ Writing } & $\begin{array}{c}\text { Pearson } \\
\text { Correlation }\end{array}$ & $.58 * *$ & 1 \\
\hline & Sig. (2-tailed) & .001 & \\
\hline & $\mathrm{N}$ & 50 & 50 \\
\hline
\end{tabular}

**. Correlation is significant at the 0.01 level (2-tailed).

The results, as Table 5 shows, indicated that there is a significant relationship $(r=.58, p<.01)$ between assertiveness and writing ability of Iranian EFL learners. Therefore, the first null hypothesis of this study is not accepted.

The effect size for correlation between assertiveness and writing ability was (eta squared $=0.61>0.14$ ) that shows the meaningfulness of the relationship between the above variables (see Table 6). One feature of an effect size is that it can be directly converted into statements about the overlap between the two samples in terms of a comparison of percentiles.

Table 6. Eta figures of correlation

\begin{tabular}{|c|c|c|}
\hline & Eta & Eta Squared \\
\hline Effect size & 0.78 & 0.61 \\
\hline
\end{tabular}

The raw scores of the participants regarding all personality behaviors, i.e., assertiveness, aggressiveness, passiveness, submissiveness questionnaire and also their writing ability scores were collected in order to investigate the second research question and hypothesis of this study on whether there are statistically significant differences among the four groups of Iranian intermediate EFL learners, namely assertive, aggressive, submissive and passive regarding their writing ability.

A one-way analysis of variance, ANOVA, was performed. The variances of all groups must be equal. Thus the Levene test was run to test the equality of variance. The result of the test, as the Table 4.6 indicates, for four groups is $p=$ $0.99>.05$. It confirms that variances of all groups are equal, so data are ready to perform ANOVA.

Table 7. Test of Homogeneity of Variances

\begin{tabular}{|c|c|c|c|}
\hline Levene Statistic & df1 & df2 & Sig. \\
\hline .036 & 3 & 46 & .991 \\
\hline
\end{tabular}

A One-way ANOVA, with the number of groups as an independent variable or factor and writing test as dependent variable was performed to verify whether there is statistically significant difference in the performance of all groups. 
Table 8. ANOVA on participants' personality and writing

\begin{tabular}{|c|c|c|c|c|c|}
\hline Score & & & & & \\
\hline & $\begin{array}{c}\text { Sum of } \\
\text { Squares }\end{array}$ & df & $\begin{array}{c}\text { Mean } \\
\text { Square }\end{array}$ & F & Sig. \\
\hline $\begin{array}{c}\text { Between } \\
\text { Groups }\end{array}$ & 217.730 & 3 & 72.577 & 4.462 & .006 \\
\hline $\begin{array}{c}\text { Within } \\
\text { Groups }\end{array}$ & 1236.258 & 46 & 16.267 & & \\
\hline Total & 1453.988 & 49 & & & \\
\hline
\end{tabular}

The performance of four groups on both tests is illustrated in Table 8. The results of ANOVA indicated that there is a statistical significant difference $\left(F_{3,76}=4.46, p<.05\right)$ among four groups of Iranian EFL learners regarding their performance on writing. Therefore, the second null hypothesis of this study is not accepted. The effect size or eta squared, according to Table 4.8 was large (eta squared = $0.49>0.14)$. It means that its magnitude is large enough to interpret that the difference among personality groups on writing test was meaningful.

Table 9. Eta figures on posttests

\begin{tabular}{|c|c|c|}
\hline & Eta & Eta Squared \\
\hline Effect size & .70 & .49 \\
\hline
\end{tabular}

\section{Discussion and Conclusions}

The results of this study confirmed that assertiveness as positive personality behavior has a significant impact on Iranian EFL learners' writing ability. It was also found that there is a significant different between different personality traits in their writing ability.

This study found different results comparing to those of [7]. He investigated the relationship between Iranian EFL students' assertiveness and their ability in argumentative speech and oral proficiency. A negative relationship was found between students' assertiveness and their ability in argumentative speech. In addition a negative correlation was found between students' assertiveness and their mastery of oral proficiency. Thus, the results of this study contradict the findings of [7].

The results of this study also were in line with what [2] found. Hemeasured the reflections of different personality types in students' developing different learning styles for themselves. The results showed that there is not a statistically strong, but a low relationship between the personality traits of the learner, the way he/she establishes the learning styles and reflects these characteristics into success while learning a foreign language.

The findings of this study confirmed the results of [3] study that found the significant influence of personality traits on the choice and use of memory English language learning strategies for learners of English as a foreign language, and the role of personality traits in the prediction of use of such Strategies. The results showed that there is a significant relationship between four traits of personality and the choice and use of memory English language learning strategies, but personality traits cannot be as a strong predictor with high percent of contribution to predict the choice and use of the memory English language learning strategies.

The findings of this study also approved the findings of [1] findings on the relationship between personality traits and EFL learners' metadiscourse competence. She found a significant relationship between these two variables.

The present study investigated the relationship between the assertiveness as a personality style and writing ability of Iranian EFL learners. It was also looked for finding the differences among EFL learners regarding their performance on writing comprehension test.

Based on the results of this study which were presented in detail in Chapter IV, the null hypothesis of the study was rejected. In other words, the research provided the evidence that there was a significant relationship between the assertiveness and writing ability. In simple terms, the higher the students' level of assertiveness, the better their writing ability.

It was also found that learners with different personality traits were significantly different from each other in their writing ability. In other words, the individual differences of learners regarding their personality styles were significantly related to their achievement in writing ability. The passive learners had the least writing ability.

\section{REFERENCES}

[1] Behtarinezhad, E. (2013). The relationship between Iranian EFL learners' personality traits and metaphorical competence. Unpublished MA Thesis. Shahrekord University.

[2] Erton,I.(2010).Relationsbetweenpersonalitytraits,languagele arningstyles and success in foreign language achievement. Journal of Education. 38, 115-126.

[3] Fazeli, H. (2012). The influence of personality traits on the use of Memory English Language Learning Strategies. Indian Journal of Science and Technology. 5(7). 3041-3046.

[4] Hartley, P. (1999). Interpersonal communication. UK: London.

[5] Hostond, T., \& Thorson, H. (1994). Writing Theory and Practice in the Second Language Classroom: A Selected Annotated Bibliography. Minesota: The Board of Regents, University of Minnesota.

[6] Myles, J. (2002). Second Language Writing and Research: The Writing Process and Error Analysis in Student Texts. TESL-EJ, 6(2). 1- 20.

[7] Omidi, N. (2004). The Relationship between Iranian EFL Students' Assertiveness and their Ability in Argumentative Speech and Oral Proficiency. Unpublished MA Thesis, Tarbiat Modares University, Tehran, Iran.

[8] Scott, J. P. (2006). Violence and the disaggregated society. 
Aggressive behavior, 1(3), 235-260.

[9] Townend, A. (1991). Developing Assertiveness. London: Routledge.

[10] Townend, A. (2007). Assertiveness and Diversity. London: Palgrave Macmillan
[11] White, R., Arndt, V. (1991). Process writing. Harlow, UK: Longman. White, R., Arndt, V. (1991). Process writing. Harlow, UK: Longman. 